\section{METALS TECHNOLOGY}

Steels for Reactor Pressure Circuits

Report of a Symposium held in London on 30 November-2 December 1960 by the Iron and Steel Institute for the British Nuclear Energy Conference. (Special Report No. 69.) Pp. vi +587 . (London: The Iron and Steel Institute, 1961.) 65s.

\section{Cold Forging of Steel}

By Dr.-Ing. H. D. Feldmann. Translated from the German by A. M. Hayward. Pp. 268. (London: Hutchinson and Co. (Publishers), Ltd., 1961.) 408. net.

Metallic Fatigue with particular reference to the Significance of Certain Standard Aircraft Fabrication and Finishing Processes

By W. J. Harris. (International Series of Monographs in Acronautics and Astronautics. Division VITL: Materials, Science and Engineering, Vol. 1.) Pp. $x i+331$. (London and New York: Pergamon Press, 1961.) 848. net.

A PART from the fact that they are concerned with metals, the three books under review have little in eornmon. One is concerned with the new technological problems that arise whon steels are used in nuclear reactors; the second is a monograph on cold forging, a relatively new method for the production of complex shapes, and the third summarizes recent experience of the fatigue of metals in aircraft and tho influence of fabrication and finishing processes.

Steels for Reactor Pressure Vessels is the report of a symposium held in late 1960 by the Iron and Steel Institute for the British Nuclear Energy Conference. This fact and the title may give the impression that the contents are highly specialized and likely to be of interest to a restricted readership but this is not the case, as is apparent on inspecting the list of titles of the papers presented.

Section 1 contains papers on the creep and graphitization of low-carbon steels, topics of considerable general interest. Section 2 deals with the corrosion of materials in reactor service. This section and that which follows, on fabrication problems, are perhaps of least interest to the non-specialist but they are, none the less, worthy of attention. Section 4 contains papers grouped under the heading "Irradiation Effocts". A careful reading of this section can only lead to a much-improved understanding of many of the problems of the mechanical behaviour of metals, particularly of brittlo fracture. Tho final section is concerned with the development of steels for future reactors; such steels are likely to have many uses outsido the reactor field, and the discussion points the way to future developments.

As is usual in the proccedings of a symposium, there is some variation in the standard of the individual papers. Howover, the general standard is high and the volume can be recommonded to any motallurgist whose primary interest is in steels.

The rapidly growing interest in the cold forging of steel in the United Kingdom fully justifies Cold Forging of Steel, the English translation of Dr. Feldmann's book Fliesspressen von Stahl. which appeared in 1959. The book brings together tho available theory and practice on this relatively new process. Practising engincers will benefit more than students from tho book for, although tho first chapter gives a reasonable theoretical introduction, a largo part is concerned with the art of designing production sequences to give desired complex shapes, the tooling of presses, surface treatments and lubrication, heat treatment and presses available for cold forging. In the numerous tables and graphs there is a vast amount of data of both practical and experimental value. It is unfortunate that Dr. Feldman could not include more information on British practice; perhaps such information must wait until British spocifications are established for steels for cold forging.

Tho author of Metallic Fatigue writes from the special point of view of the aircraft industry in which he has had considerable experience. Though there is some reference to the role of dislocations, the approach is essentially that of the engineer, and the main emphasis is on stress concentration and its alleviation, crack propagation, corrosion and fretting rather than on the physical metallurgy of the fatigue process. The volume is a useful addition to the literature and will certainly be welcomed by those primarily concerned with practical aspects of fatigue and its avoidance, whether in aircraft or in more general applications.

A. G. Quakreti

\section{ART AND CRAFT OF BUILDING}

\section{A History of Building Materials}

By Dr. Norman Davey. Pp. xiv $+260+48$ plates. (London: Phoenix House, Ltd., 1961.) 65s, net.

$\mathrm{W}$ E now seem to be in an age of monster-some would say monstrous-buildings, primarily functional in intent, and expressing the skill of the engineer rather than that of the craftsman. The matorials used, steel, aluminium, concrete, glass and plastics, are usually fabricated and shaped before reaching the building site. The same tendeney is affecting the methods of building ordinary dwelling. houses, where the use of such traditional materials as stone, plaster, timber and oven ordinary bricks is passing, together with the skills used in their application. This chango seems inevitable, but to many it is a matter for regret.

Dr. Norman Davey, who spent many years on the staff of the Building Research Station at Watford, has produced a most readable account of the building materials usod in the past, from palreolithic times onwards, mainly in Europe and the Mediterranean region, though ho sometimes goes farthor afield for his examplos. These materials are very varied in character, ranging from reed and straw thatch to timber, from un-dressod stone to bricks, slates and tiles, and includo substances such as terra cotta, plasters, limes and cements, bitumen, stucco and so on. The title of the book is misloading. in that it does not indicate its full scopo, for, in addition to deseribing the nature and mode of preparation of typical building matorials, and the precise uses to which they have been put, the structural details of buildings in which they were used have boen deseribod and illustrated. Thus, in outline, at least, the book is a history of the art and craft of building. The skill and ingonuity with which traditional naterials were used in the past, not only functionally but for ornamental purposes, has been depicted in the fortyeight plates and one hundred and thirty-four elear and attractive line-drawings which supplement the text.

The concluding chapters diseuss the use of glass and motals in building and such complementary 